\title{
JOHANNES DE WITT'S VISIT TO THE SWAN THEATRE.
}

In 1888, Dr. Gaedertz published his interesting account of a new theatrical find at the Utrecht University Library ', taken from the newly discovered transcript (by a Mr. van Buchell) of the papers of a Dutch savant, Mr. Johannes de Witt. I may perhaps, with one word, remind my readers that the find consists in a drawing of the interior of a Surrey-side theatre, 'te theatre off te cyn' (Swan) with an accompanying description. In this drawing we see the confirmation of many suppositions made as to details of the $16^{\text {th }}$ century theatre and from the (latin) description we get some interesting information about the structure of the Swan - a valuable supplement to what we could guess about it from the account of the construction in 1613 of the Hope-theatre, which was to be "of as large a compasse and height as the plaie-howse called the Swan." 2

The drawing was given by Gaedertz as a frontispiece to his work and has since been reproduced by Ordish (1l. p. 265) and also by Bapst in his excellent work on the History of the Theatre. ${ }^{3}$ We are not so much concerned here with the inside view of the Swan as with the question: Which play or rather which scene is depicted here as being enacted on the stage? We see - in plain words - two females of whom one is seated, whilst the other is standing behind her - and a man approaching these two, with long strides, and with some long staff in his hand. Those are the bare facts, about which there can be no dispute. Dr. Gaedertz,

1 Zur Kenntniss der altenglischen Bühne etc. Bremen. C. E. Müller, 1888.

2 Ordish, Early London Theatres. Elliot Stock, 1894, p. 217.

${ }^{3}$ G. Bapst, Essai sur l'Histoire du Théatre, etc. Paris, Hachette, 1893, p. 265. 
as in duty bound, has asked himself the question which play de Witt may have seen performed on this for us so memorable day. Dr. Gaedertz does not know. And yet it would be interesting enough if we could find it out. I am not aware that any hypothesis has been offered by way of solution of this difficulty, - with the exception of Dr. L. Fränkel's who is reminded of a scene in Macbeth. ${ }^{1}$ I would like to bring forward an other hypothesis which as such must be left without more ado to the appreciation of Shakespeareans, it is of course, from the very nature of the case, absolutely unsusceptible of proof.

As it is preferable to give an unsuspected testimony, we shall first see what impression the scene, as represented in our drawing, made on Dr. Gaedertz himself, who did not of course think of my hypothesis. I give it as much as possible in the exact words of Dr. Gaedertz' Academy critic ${ }^{2}$, Karl Blind. If I were to give my impression in my own words, I should be more liable to introduce elements into my description, foreign to the intention of the artist. I would ask my readers to go and do likewise, i. e. to act upon this hint and see if they are not reminded of a scene in one of Shakespeare's comedies when looking at the drawing. If they were to hit upon the same as I, it would be a desirable additional testimony to the probable accuracy of the impression.

According then to Dr. Gaedertz, we see on the seat a female whose dress is too indistinctly drawn to enable us to come to any conclusion with regard to her costume. The female standing next to her ${ }^{3}$ is in Elizabethan dress, - 'they seem to be the Queen and a Lady of the Court'. Both look towards the approaching figure to their left. This figure, says Dr. G. is a messenger, adorned with a martial Henri-Quatre

1 See 'Englische Studien' 15. 441. 'If Shakespeare's Macbeth were not younger by a decade' - Dr. Fränkel evidently accepts Dr. Gaedertz' date of 1596, of which more anon, and takes Macbeth to have been written in 1606; I would assign it to 1603 - 'I would be inclined to think of Macb. I. 4. $31 \mathrm{ff}$.' Surely, there must be a misprint here, - but which other scene can Dr. G's critic have had in his minds' eye?

Academy, June 8, 1888, p. 390.

8 'ihr zur seite', but it is important to note that the standing figure is seen behind the seat, which Dr. G. does not indicate. 
beard and he has evidently to bring a message of importance to his Lady. He runs up to her, lance or staff in hand, with seven league strides.

Now for my own impression. I seem to see more than 'a messenger who brings important news' in the male figure. It had struck me from the very first time when I saw the drawing in 1889, that there was something fussy in the way in which the man strides along, - at the same time he gave me the impression of self-satisfaction, which can not be due only to his 'pickadevaunt' and his beautiful moustachios. In one word, - the man reminded me irresistibly of Malvolio, Shakespeare's immortal majordomo in Twelfth Night.

Visitors to the Vernon Collection in the National Gallery may have noticed a very able painting by Maclise (No. 423) called "Malvolio and the Countess". It so happens that in this picture we have exactly the same disposition of figures as in de Witt's drawing, - the Countess is sitting on a low bench, Maria is standing laughing behind her back - i. e. behind the seat, - they both look towards Malvolio. The only difference is that Malvolio stands right in front of them and is smilingly waving kisses with his left hand, whereas in his right he holds his hat and the staff of office (which will also be noticed in the Swan-drawing). This coincidence is of course not adduced here to prove in any way my point that our drawing must represent this scene in Twelfth Night. What it does prove however - if such a point needs proof at all - is that it may represent such a scene. And if so, there can be no doubt about the question as to which scene. It must then be the fourth scene of the third act. Maria it will be remembered - has written her mysterious epistle to Malvolio to make him believe that Olivia is in love with him, - and in consequence of certain hints contained in this letter, Malvolio comes to find his mistress. Maria has seen him coming (or, knowing him and the effect her letter will be sure to have on him, makes bold to prophecy how he will present himself before the countess) and says: 'He's coming, Madam, but in very strange manner. He's sure possessed, Madam, ... he does nothing but smile', - and his subsequent behaviour is such as to give Olivia the right to think that with him it's really 'midsummer-madness'. 
Let us now look at de Witts drawing again and we shall see that so far as this representation goes, there can hardly be any objection to my hypothesis. The standing female whom I take to be Maria has seen Malvolio coming and has addressed the words quoted to her Mistress. Malvolio, staff of office in hand, is on the point of arriving, - his attitude must have made a considerable impression on de Witt to make him choose just this momentary, passing, 'dissolving view' for reproduction. Maclise's picture would therefore represent a moment coming directly after that, rendered in in de Witt's drawing.

Most of my readers, if not all, will, I presume, have already mentally objected that my hypothesis can not be supposed to hit the truth, seeing that, according to Dr. Gaedertz, de Witt's visit to the Swan took place in 1596, whereas Twelfth Night is usually assigned to 1602 , at any rate to a date, later than 1596.

It must therefore now be my task to prove that neither date is absolutely certain. We shall find that so far as the arguments are concerned that have hitherto been brought forward, Twelfth Night may have been written long before 1602 and that on the other hand, de Witt's visit to the Swan need not have taken place in 1596 , but may on the contrary have to be dated a couple of years later.

I. 1. The opinion of Malone who placed it ab. 1607 and that of Chalmers and others who put it ab. 1613 need not detain us long. If there is any thing philologically certain, it is that the account of Manningham, who had witnessed 'a play called Twelve Night or what you will' ' on Candlemas day 1602, refers to our Shakespearean play. As nothing forces us to believe that Manningham here witnessed a première, this date is a terminus ad quem, but need not be one a quo.

2. Halliwell Phillips and others, e. g. the latest Biographer of Shakespeare, Georg Brandes, think that Tw. N. must have been written in 1601 . This "may be gathered from the use Sh. has made of the Song 'Farewell, dear Love' - a ballad

1 cf. Collier H. E. Dr. P. ed. 1879, I. 315. 
which had first appeared in the previous year in the Booke of Ayres composed by Robert Jones, fol. London 1601" 1 First of all, I must object that, although this song may have been published for the first time in 1601 (and who knows but it may be discovered to-morrow in an older collection!), nothing precludes the possibility that it should have circulated in Ms. before - a common practice in those times -, or that it should have been a well-known ditty which Jones had taken from oral tradition. It must be remembered that, as Halliwell himself tells us "Jones does not profess to be the author of the words of this song, for he observes: "If the ditties dislike thee, 'tis my fault that was so bold to publish the private contentments of divers gentlemen without their consents, though I hope not against their wils".2 I would moreover ask my readers to go through the scene once more, in which these lines occur - II. 3. 109 etc. - and see if my impression is not correct that they could only have been introduced in the way it is done, if the song from which they are taken were generally known. ${ }^{3}$ Malvolio happens to use the word 'farewell', and Sir Toby at once catches him up: 'Farewell dear heart, since I must needs be gone'. The exact bearing of Maria's 'Nay, good Sir Toby' is perhaps doubtful. It might be supposed to mean 'Nay, do nót go' if taken literatim, which would indicate a misunderstanding of, therefore unfamiliarity with the song on the part of Maria. The context however, seems to me to require that we should take Maria's words to be a remonstrance with Sir Toby for disregarding Olivia's injunctions. But the point is immaterial, for, as will be remarked, it is not Sir Toby who goes on with the quotation from the same song, but the Clown; the best proof that Shakespeare intended to represent his two characters (at least) as knowing the song in question, which means, if anything, that it was familiar to the audience too. His personages in this scene are continually quoting from well-known ballads, such as "Of

${ }^{1}$ Halliwell, Outlines of the Life of Shakespeare $8^{\text {th }}$ Ed. II. 251 f.; the same reasoning apud G. Brandes, W. Shakespeare I. 322.

${ }^{2}$ Halliwell's next words to the effect that 'there is every reason to believe that the rerses referred to in Tw. N. must form an exception' is a gratuitous assertion for which there is no foundation whatsoever.

3 See the song reprinted, e. g. by Delius I. $483,484$. 
the goodly constant wife Susanna". And, just as, a moment later on, the Clown, who d oes understand the allusion, answers Sir Toby as though he took Sir Toby's quotation "But I will never die" seriously - he says: Sir Toby, there you lie" even so Maria may do as if she took Sir Toby's words seriously in the presence of her lady's majordomo.

My conclusion is that the song does not prove the date of Twelfth Night to have been 1601, - it proves just nothing at all.

3. According to some commentators Twelfth Night must have been written before 1598 as Jonson's Everyman out of his humour contains a passage which is - by them - supposed to be a reminiscense of Shakespeare's play. It is found in III. 1. A Comedy is there spoken of, the argument of which "might have been of some other nature, as of a duke to be in love with a countess and that countess to be in love with the duke's son, and the son to love the lady's waiting maid; some such cross-wooing with a clown to their serving man" etc. Georg Brandes (1l. p. 323) who, as we have seen, believes Twelfth Night to have been written in 1601 , goes even so far as to suggest that this passage must have been inserted afterwards into Ben Jonson's 'Everyman out of his humour', - this play having been represented in 1590 .

Everything depends upon whether we can allow for some not-unimportant divergences between Twelfth Night and this supposed reference to it; if we can allow, that is, Jonson's memory to have been so much at fault as to serve him the turn to make him write of the love of Olivia for the Duke's son, whereas Orsino has no son and to make this non-existent son fall in love with Maria. I am obliged to say that to my thinking the answer can be hardly anything but negative, however much I would like to come to an opposite conclusion. One thing is not too much to say, viz. that we cannot accept it with certainty. Hence: this passage does not allow us to draw the conclusion that Tw. N. must have been written before 1598 .

4. Some critics argue on the other hand that it did not yet exist in 1598 as Meres does not mention it among Shakespeare's plays in his 'Palladis Tamia or Wit's Treasury', 
published in that year. Again there is no force whatsoever in this argument.

First of all: something might be said in favour of it, if we could be sure that Meres intended to give the titles of all the plays, but I think he "mentioned the more important ones by way of example - six of each of the two species" as Elze ${ }^{1}$ rightly observes. For, to any one who will read through Meres' account, it will be apparent at a glance that Meres goes in for some sort of parallelism, - if he can possibly manage he quotes the same number of authors in Latin, Greek and English; the same number of examples of the works of each; the same number of instances of each species. In short we find a sort of Euphuistic balancing of periods. I think at least $I$ am justified in drawing this conclusion as in the great majority of cases I found this rule to hold good. So, his mentioning six comedies and six tragedies is probably no coincidence, it is quite possible, if not probable, that Shakespeare had written more. If so, Tw. N. might have been among the number.

We must now discuss the main question: Although Meres' Palladis Tamia was published in 1598, may it not have been written long before? Meres would then simply not have included the Tw. Night because at that time Sh. had not written it. Literary productions often circulated in Ms. and were printed, perhaps years afterwards. This was indeed a very common practice. If it is necessary to quote instances - many are available -, I would remind the reader of a play which the author brought before the public, only because a surreptitious copy - these words will conjure up quite a host of illustrations before your minds' eyes - had been printed. I am thinking of "Roxana Tragaedia A plagiarii vnguibus vindicata, aucta, et agnita ab authore Gulielmo Alabastro". 2 And such a belated publication is of frequent occurrence.

1 Elze, W. Shakespeare. English Translation by D. L. Schmitz. Bohn 1888 , p. 299.

${ }^{2}$ Published in 1632 by W. Jones. Another ed. of which a Copy is in the B. M. (with the title 'Roxana tragoedia .... nunc primum in lucem edita) ..... and which was published also in 1632 by $R$. Badger in London, seems to me to be the pirated edition. I quote this one instance in pre- 
For all that it can easily be made all but certain that the Palladis Tamia cannot have been written so very long before the date of publication. For we shall see infra sub II. 1 that it must have been finally prepared for the press - if not written - after 1596, as the Swan Theatre which Meres mentions cannot be shown to have been built until that year. Mr. Fleay ${ }^{1}$ goes even a little further. "A careful comparison of the list of dramatists" (mentioned in P. T.) "with that of known plays or titles of plays that have come down to us shows that the P. T. could not have been completed for the press" (on which words I would lay due stress) "till June 1598". This is a statement difficult to control, and as I cannot now do so, I must rest content with this conclusion, negative as it is: With regard to the probable date of the Palladis Tamia: 1596-1598, and with regard to the Twelfth Night: none at all.

5. Mr. Fleay is of opinion that some scenes were written in 1592 or 1593 and that it was completed in 1601 or 1602.2

The earlier scenes do not, according to him, include the scene that we have here more especially in mind. Quite independently of Fleay, it would seem, a recent writer in the Shakespeare-Jahrbuch, Dr. H. Conrad, has tried to prove from the resemblances with earlier and later works with a view to poetic formulas and poetic structure (Gehalt) that those parts of Tw. N. that contain the Viola-episode belong to 1590-1595, - the scenes dealing with the Malvolio-

ference to others because the author himself, in his preface, tells us that it was written as early as forty years before, and because it gives me an occasion of correcting a slight mistake that Dr. Gaedertz has fallen into. He says (p. 4) that until the time of his publication, the view of the Red Bull interior (apud Genee, the Mermaid-Heywood etc.) was the earliest known. As a matter of fact, two of the three copies of Alabaster's own 1632 ed. of the Roxana in the Bodleian Library contain a very interesting frontispiece, showing an interior view of a theatre, which must therefore be dated 1632 at the latest. With the kind permission of Bodley's Librarian I had it photographed for publication, when I found that it was already made public by Knight. See his Pictorial ed. of Shakespeare's tragedies vol. I p. 56. He reproduces the principal part of the frontispiece and describes it. A similar view appears to be found in a play 'Messalina' 1640, which I have not seen. See Notes \& Queries 7th S. VI. p. 221.

1 Life of Shakespeare p. 135.

2 See his Life of Shakespeare pp. 44, 111, 145, 219 and his Chronicle History of the Drama II. 177. 190. 
episode were written by the end of the century, - when the whole was recast. It will be noticed that according to both critics, the Malvolio scene - with which alone we have to occupy ourselves - dates later. The question must therefore be mentioned merely for completeness' sake, and need not be entered into. The point is not established apparently, however plausible it seems. See Prof. Sarrazin's paper 'in the next volume of the same publication. ${ }^{1}$ No definite result for the question in hand.

6. Dr. Conrad (11.) quotes a line from Jonson's Poetaster (IV. 3): "I have read in a book that to play the fool wisely is high wisdom", compares this with Twelfth Night III. I. 67, and argues that as the Poetaster must have been written in 1600 at the latest, Twelfth Night must probably be dated 1599. This evidence does not appear to me conclusive as the maxim that "to play the fool wisely is high wisdom" does not seem to me of a nature to exclude the possibility that two or more people could have hit upon the saying, - slightly differently expressed as the two utterances are - independently of each other. I confess to being unable at present to adduce any similar saying from other authors, but this cannot invalidate my point which is unfortunately only negative, viz. the Poetaster consideration does not give us any certainty. Moreover: if there should be any similarity, any imitation, both may have read it in the same book. (In Montaigne?)

7. Knight and others base an argument (to the effect that Twelfth Night must have been written posterior to 1598) upon the passage III. 2. 84: "He does smile his face into more lines than are in the new map with the augmentations of the Indies". We must remember that 1598 is the year, when this certain map was supposed to have been issued. I hold with Dr. Conrad (ll. 198) that the conclusion as such is inadmissible. Moreover this so called map of 1598 does not appear to contain these 'Augmentations' The argument therefore falls to the ground.

8. Dr. Conrad (ll. 198) accepts an explanation of III. 2. 28 'you are now sailed into the north of my lady's opinions, where you will hang like an icicle on a Dutchman's beard',

I Shakespeare Jahrbuch $31 ; 177$ and ib. 32; 164, 167. 
as suggested to him by Mr. L. P. H. Eykman of Holland. According to this explanation the passage quoted would be a reminiscence of the well-known Barends-expedition into the Arctic Seas. This suggestion is worthy of consideration, - if nothing else comes to overthrow it, it would prove that 1596 were terminus a quo.

None of the various points hitherto considered ' make any more definite conclusion possible than at the most the very meagre one that Twelfth Night must have been written between 1596 and 1602.

II. The Date of de Witt's visit to the Swan is given by Dr. Gaedertz as 1596. So far as I can see this date has generally been accepted. It has at any rate already found its way into a couple of subsequent publications. ${ }^{2}$ Dr. Gaedertz himself is at fault here. He was imprudent enough to state under the reproduction of his drawing that it is executed "after a drawing at Utrecht of the year 1596 " 3 as though there were no doubt about it, - whereas in his text he discusses the matter very fully, without in any way speaking of a certainty.

It will be proved however that although it can hardly have been before 1596, it may very well have been after.

1. What seems to be Dr. Gaedertz' first argument is (p. 7 etc.) that de Witt mentions four theatres worth seeing on account of their beauty (visendae pulcritudinis) - he mentions especially the Rose and the Swan, and says of the two others that they were situate "via qua itur per Episcopalem Portam, vulgariter Biscopsgat nuncupatam." Any student of the Theatre - or better of the Theatres - of that period will recognise the 'Theatre' and the 'Curtain'4. If 1596 were the only year in which these theatres existed, Dr. Gaedertz'

1 See below p. 132.

2 See Ordish p. 266 ; Karl Blind, Acad. u. s. p. 390 ; etc.

8 'vom jahre 1596'; he should have put: 'u m (about) das jahr 1596'.

- As a proper name the 'Curtain' is untranslatable, and it should therefore never have been translated by 'Vorhang' as Dr. Gaedertz does. For this suggest to the unwary that it has something to do with a 'Vorhang' = Curtain, whereas as a matter of fact, it has got this name from a piece of ground which was thus called for some unknown reason and where, in 1576 or 1577 , this theatre was erected. (Halliwell Outlines I, 364.) 
date would of course stand. But this is not so. We may begin by concluding in a general way that so far as this argument is concerned de Witt's Visit must have taken place between the moment when the last of these four theatres was erected and that when one of them was taken down. The Theatre is to be dated 1576-1598. The Curtain from 1576 or 1577 till at least 1627.1 The Rose from 1592 or before till at least $1603 .{ }^{2}$ The date of the erection of the Swan must here be discussed more in detail. It did not disappear until long after the Theatre.

On p. 8, Dr. Gaedertz says that the date is probably shortly after Xmas in January 1593 "at any rate before" the time of the Blackfriars-episode i. e. 1596, 1597. On p. 12, Dr. Gaedertz having forgotten his prudent 'probably' of p. 8 says it was built, 'in or about 1593 as I think to have proved'. This date does not seem to me exact. From a letter of the Lord Mayor to the Lord Treasurer of Nov. 3. 1594 it appears that the Swan was then not yet erected. ${ }^{3}$ "In 1595 another letter to the same effect" says Mr. Rendle. ${ }^{*}$ So it could hardly be until later in 1595 or 1596. And as we know that Francis Meres mentions the Swan theatre in his Palladis Tamia, printed and published in 1598 (June) it must have existed in that year. Moreover it was in this same year, in 1598, that the vestry of St. Saviours ordered Mr. Langley's (the proprietor's) new buildings to be viewed. 5

The construction of the Swan theatre must therefore be dated between some time late in 1595 and sometime in June 1598.

So: of these four theatres the Swan was the last to be erected, and the Theatre the first to disappear. Hence the visit of de Witt so far as the argument of the existence of these four theatres is concerned ${ }^{6}$, is to be placed between some time late in 1595 and the $20^{\text {th }}$ of January 1599 (at the very latest, probably only the $28^{\text {th }}$ of Dec. 1598) the date when 'the Theatre' was finally pulled down and when

1 Perhaps 1647, Ordish 1. 1. p. 107.

2 Ordish ll. pp. 154 and 200.

3 Ordish p. 253.

- N. \& Qu. u. s. p. 222.

5 See Ordish p. 258; Rendle, N. \& Qu. u. s.

- Please to note the spaced words. 
its materials were brought across the water to serve for the construction of the Globe. 1

2. Dr. Gaedertz' second argument is as follows: de Witt does not mention Shakespeare, who was a famous man. De Witt is in the habit of looking up all famous men in his foreign travels, - consequently: he must have been in London at a time when Shakespeare was not there. Shakespeare was absent in 1596, - therefore de Witt must have been in London in 1596.

If we begin by meeting Dr. Gaedertz upon his own ground, we may ask: As we have not got de Witt's original, complete, account of his journey to London, may not de Witt have spoken of Shakespeare in some other place, in a document which is now lost? Again: must we suppose all the famous men whom de Witt does not mention to have been away from London at the time of his visit? To mention only one: was rare Ben away then too? Or was he not famous enough? $\mathrm{He}$ is at any rate not mentioned in the Buchell papers. ${ }^{2}$

But we need not go on in this supposition, for an argumentum ex nitilo is always dangerous.

Moreover we know nothing whatsoever with any certainty about Shakespeare having been away in 1596. His son Hamnet was buried on August $11^{\text {th }}$ of that year. Hence Dr. Gaedertz concludes that Shakespeare was 'unquestionably' absent in that year. This is building on very slender foundations. ${ }^{3}$ Supposing it to have been so, however, for a moment, must Shakespeare have been away all the summer? Here the argument breaks down already. Moreover, is it likely that he was away? When the news reached him of Hamnet's death, would it not have been too late for him to get to Stratford in time for the burial? + We can hardly expect him to have been summoned away by telegram just in time to catch the evening express? There are other considerations against this notion which I forbear to enter into. That Shakespeare

1 Halliwell Outlines I, 361.

2 Gaedertz, p. 56.

$8 \mathrm{Mr}$. Fleay too says: 'Hamnet's father was undoubtedly present' (at the burial) and adds: 'This is the first visit to Stratford on his part since 1587 so far as any evidence' (!) 'exists.'

- See next paragraph. 
must every now and then, - or shall we say : once or twice? have returned to his native place is possible; it is indeed probable. But this would more likely have been when he found he must attend to some business, such as when in 1597 he purchased New Place, 1 - i. e. a visit which he could have foreseen and prepared. Suchlike visits we may take into account. Dr. Gaedertz mentions this 1597 visit but leaves it alone since it does not suit his argument, - in which for the matter of that he is right.

Although the presence of Shakespeare at his son's death is by no means impossible, - he may have been there by a curious coincidence or, for aught we know, Hamnet máy have been ailing for a very long time, so that his father could indeed have prepared and arranged for this visit - I think we must conclude with the late Halliwell-Phillips that "There is not an atom of evidence that Shakespeare was at Stratford in 1596." 2

3. Nor does de Witt's silence about the Blackfriars-theatre prove anything. It must have been opened in 1597.3 Now, Dr. G. argues, hal de Witt been in London in winter-time he would 'perhaps' (the word is of Dr. Gaedertz) have given us a view of that theatre, and of a Shakespearian performance. In Dr. G's own sphere of thought we may say: Even had the Blackfriars' theatre existed during de Witt's Visit, he might have preferred to speak of the four others, as being of greater 'pulcritudo'. And if my hypothesis be true he did describe a Shakespeare performance.

But by way of commentary on his argument it is unnecessary to go beyond Dr. Gaedertz's own: 'perhaps'!

4. A further argument is drawn from a Journal of a trip made to London in the year 1596 by Prince Ludwig of Anhalt, who also mentions four theatres, just like de Witt. Dr. Gaedertz arrives at the conclusion that therefore de Witt's finding four theatres must also have been in the same year.

1 Fleay, Life of Shakespeare, p. 129.

2 Ordish, p. 266. I do not know to which 'condition of the period' Mr. Ordish refers in a note on this page 'which would account for Shakespeare's absence at the time of his son's death'.

3 Halliwell, Outlines I, p. 304.

Anglia. N. F. VII. 
The reasoning is by no means free from objection. If the German Prince had mentioned the same four theatres by name - but only then - all the conclusion we should be justified in coming to, would be that the visit of de Witt and that of Prince Ludwig must have taken place in the same lapse of time, - see supra. A conclusion which would not help us much. But as the Prince mentions no names at all, the possibility is not excluded that he was thinking of other theatres. However, granted that the German visitor really had in view The Theatre, The Curtain, The Rose, and the Swan - which is certainly not impossible - I fail to see in how far this proves that de Witt could not have seen those same four theatres in 1597 or in 1598, - see above.

5. Hentzner in his Itinerarium (1598) tells us that representations took place 'singulis fere diebus'. Dr. Gaedertz jumps at the conclusion (p. 17) that accordingly no performance took place on Sundays, ${ }^{1}$ and therefore, that de Witt, who speaks of daily performances, múst have been in London before this year. Both expressions however, Hentzner's as well as de Witt's 'varia quotidie scaena exhibetur' may after all mean one and the same thing. Dr. Gaedertz evidently takes 'quotidie' to refer to 'exhibetur'. But it may also refer to 'varia' on which supposition we get this: every day something different is to be seen there. This may seem in contradiction with such a statement as that e. g. the Admiral's men 'produced a new play every fortnight or so', and the Chamberlain's men 'not more than four new plays a year'.2 But if it is remembered that the 'varia scaena' may refer to the four theatres (in iis, says de Witt) and that a certain piece could never have the; same run as nowadays, we are forced to the conclusion that this 'quotidie' cannot possibly be taken in the strict sense of "every day" (a performance, new or otherwise). And if it cannot be taken literally, there is no difference between this statement and Hentzner's 'singulis fere diebus'.

Dr. Gaedertz' conclusion tallies so well with my conten-

1 This question seems immaterial, but where does Dr. Gredertz get it from? He uses it for another uncalled for conclusion about the Puritans.

2 Fleay, Life of Shakespeare, p. 284. 
tion that the visit must be dated some time between late in 1595 and 1598 that I would fain accept the argument. But I am afraid it won't stand - I am perhaps hypercritical.

6. De Witt mentions a monument in Westminster Abbey, adding that it was placed there in 1596. 1 Hence says Gaedertz, de Witt must have been there in or after 1596. This is indeed a very likely conclusion, but I lay due stress on the words: 'in or after'.

From all this it appears that de Witt's Visit cannot with any degree of certainty be located more precisely than by saying that it must fall between 1596 and 1598 .

III. Putting side by side the results arrived at in what precedes, we find that Twelfth Night, which must have been written between $1596^{\circ}$ and 1602 , may very well have: been seen performed at the Swan theatre by a foreigner who visited England between 1596 and 1598. This conclusion gives us at the same time the probable terminus ad quem of 1598 for Twelfth Night.

I have purposely abstained from entering on debatable ground.

If we could assume with any semblance of certainty that "Mr. Langley's New buildings" in 1598" meant that they dated from that year, we should get the more precise date: spring 1598. This is indeed not impossible in itself, for these buildings were visited, it would seem for the first time, with a view to have Mr. Langley "moved for money for the poor in regard to the playhouses and for tithes" and this is likely to have happened directly or very shortly after they had

1 This is Dr. (') way of looking at the question (p. 52). As a matter of fact de Witt merely mentions the year 1596; it seems to be somehow connected with the monument. "Ibidem in rede Westmonasteriensi sunt monumenta .... G. Thynne .... qui obiit 14 Martii 1584. item Johannis Bourgh Duisburgi gubernatoris Ao 1596. As de Bourgh died in 1594 and as the memorial tablet to the monument seems to have been placed there in 1595 (Dr. G. p. 54) de Witt's 1596 looks like a mistake in any case. But - unless it be a mistake on the part of van Buchell in his transcript! 1596 very likely constitutes a terminus a quo, - but nothing more!

2 See above p. 127. This would at the same time give Mr. Fleay another proof that his date of June 1598 for Meres' Palladis Tamia was right. Supra p. 124. 
been erected. Again: If the date of the Bourgh-memorial as given by Dart in 1723 ' were right, who puts it in 1598, we should have the likely date 1598 once more. But 'there's much virtue in If' and two 'likely's do not make one truth. ${ }^{2}$

One more question must be touched upon before we finish. It will be asked if we have any evidence of any Shakespearean play having been acted at the Swan. The answer must be negative. But this does not overthrow our argument.

I must begin with a warning. Messrs Halliwell Phillips, Fleay and Ordish, to mention only the principal men, have done very good service in bringing something like a beginning of order in the chaotic mass of documents which tell us of certain companies having acted at certain times in certain theatres. But it is only a beginning and at every page we meet with difficulties, contradictions and unsolved problems. The time has unfortunately not yet come that we can base a safe argument on the indications we get in this line. But I have to prove in the subsequent section that a Shakespearean play may have been acted at the Swan in 1596-1598, although we have no evidence to this effect. And I do not claim to do so because the considerations that I shall bring forward must necessarily be true, every one of them. This will possibly, nay probably not be the casc, as I explained before. But if we find Mr. Fleay or Mr. Ordish assume, that in one or more particular cases,

a. A Shakespearean play was acted by a Company with which Shakespeare was not connected (or, for the matter of that, more generally

$\beta$. That a Company acted a play of an author unconnected with that Company), or that

$\gamma$. A Shakespearean play was acted by his Company at an other theatre, than those with which we know Shakespeare to have been habitually connected;

1 Gaedertz, p. 53.

2 On the $28^{\text {th }}$ of July 1597 the Theatre was finally closed, says Mr. Fleay. Chr. Hist. p. 134. If any positive evidence of this date exists, which I can not see, it would seem to narrow down the period in discussion to 15961597 (July 28), but it looks suspicious. See l. l. p. 145 where the Lord Chamberlain's Company is stated to have acted at the Theatre until Oct. 1597. Moreover nowhere does de Witt state that performances were actually taking place at the Theatre during the time of his visit. 
if any of these eventualities may be supposed to have occurred, or only one of them, then I maintain we have a right to conclude that Twelfth Night $m$ ay have been acted at the Swan, either by another Company, or by Shakespeare's Company; and this conclusion would stand even if, at a certain moment, the examples which I shall have to quote should prove false.

$\alpha$. On January $23^{\mathrm{d}} 1594$, the Sussex men act 'Titus Andronicus' at the Rose.' But as we are not sure that the play was Shakespeare's, the case is a doubtful one and perhaps not in point.

The Revels' Company and the Admirals' Company's players are supposed to have acted many of Sh's plays. ${ }^{2}$ But this was in Germany, so again our case is doubtful.

$\beta$. See Mr. Fleays Section VI of his Life of Shakespeare. "On the plays by other authors acted by Shakespeare's Company"." Here the reader will find many plays mentioned by authors, who were unconnected with Sh's Company. To quote only one instance: "On March $3^{\mathrm{d}}$ 1592, Lord Strange's men (= Sh's Company according to Fleay) acted a new play, which Fleay supposes to have been written mainly by Marlowe. ${ }^{4}$ And it must be especially noted here that Marlowe was at thát time a Pembroke-man!s

Plays are moreover known to have passed from one Company to another. "In May 1593, 2 Henry VI" (supposed to be Marlowe's) "passed to the Sussex-men with Leir" (the old play) etc. ${ }^{6}$

$\gamma$. Shakespeare's name is found as a member of the Earl of Leicester's, Lord Strange's, Lord Derby's, Lord Hunsdon's, the Lord Chamberlain's, and the Kings' men. These companies or this company - for it may be only one ${ }^{\top}$ - are known to

1 Fleay Life of Sh., p. 114; Ordish, p. 164.

${ }^{2}$ Fleay, ib. pp. 307, 315.

3 See also Fleay, Chron. History pp. 154-157.

- Fleay, Life etc. pp. 108, 109.

5 Fleay, Chr. Hist. p. 74; Life p. 273.

- See Life, etc. pp. 268, 273. Also, Chron. Hist. p. 81. On the manner in which a company might get at a play, Life p. 151 .

7 According to Mr. Fleay, Shakespeare was a member of only one Company which went by these various denominations (Life, etc. pp. 92-94). As the question does not affect our argument we need not discuss it. 
have acted at the Theatre, the Curtain, the Globe, the Rose, St. Pauls, The Fortune, Newington Butts, Blackfriars, besides at Gray's Inn, the Court, and in other towns of England, as well as perhaps in foreign countries. ${ }^{1}$

So why should this Company not have acted at the Swan? When glancing at the preceding paragraphs, I think, we can hardly avoid the conclusion that, from this point of view too, my hypothesis is free from objection.

I understand that Twelfth Night is to be produced by the Elizabethan Stage Society this winter in the splendid Old Hall of the Middle Temple, where Manningham saw it acted nearly three centuries ago. If my hypothesis be accepted, the possibility exists for the first time that a Shakespearean scene may be said to be represented "after a contemporary reproduction of the same."

1 Fleay, Life etc. pp. $92 \mathrm{ff}$., $106 \mathrm{ff}$., 125 ff., $138 \mathrm{ff}$; Chron. Hist. pp. 82, $95 \mathrm{ff} ., 133 \mathrm{f}$; Ordish p. 102.

Ghent, Belgium, August 1896.

H. Logeman. 